\title{
Risk Assessment Methodology in SME
}

\author{
Hana Pačaiová ${ }^{1 *}$, Anna Nagyová ${ }^{2}$, Zuzana Kotianová ${ }^{3}$, Aleš Bernatík ${ }^{4}$ \\ 1,2.3 Technical University of Kosice, Faculty of Mechanical Engineering, Department of Safety and Quality, Lena 9, 04200 Kosice \\ ${ }^{4}$ VSB - Technical University of Ostrava, Faculty of Safety Engineering, 17 listopadu 15/2172, 70833 Ostrava - Poruba, Czech Republic
}

\section{BIOGRAPHICAL NOTES}

Hana Pačaiová, prof., Ing., PhD., 7.6. 1962; graduated 1987 at Technical university of Kosice, Mechanical engineering faculty. Position: professor, deputy of head of Quality and Safety department; specialization: Maintenance Management, Risk Management; Member of Accreditation commission for National Labor Institute (Education), Board Member of Slovak Maintenance Society, Board Member of Slovak Technical diagnostics Society, Member of European Health and Safety Committee (EFNMS), Technical expert of SNAS. Author of several professional publications on occupational safety, major hazard, and maintenance management areas - magazines, conferences.

Anna Nagyová, Ing., PhD., 19.12.1979, graduated in 2003 at Technical University of Kosice,Faculty of mining, ecology, control and geotechnology - major field Management Quality. Current position: assistant lecturer. Specialization: management systems, project management. She is author of more than 40 publications in the area of quality control, team member of several national and international projects.

Zuzana Kotianová, Ing., PhD., 4.5.1982, graduated in 2005 at Technical university of Kosice, Faculty of Mechanical Engineering. Current position: assistant lecturer. Specialization: Risk Management. Author of several professional publications on occupational safety and major hazard accidents - mainly sources with below-the-threshold quantities of hazardous substances. Team member of several national and international projects.

Aleš Bernatík, assoc. prof., Ing., PhD., 2. 10. 1972, graduated 1995 at VSB-Technical University of Ostrava in area of Environmental Protection, doctor in Methodology for Industrial Risk Assessment, in 2007 was habilitated. Position: the vice-dean for science and research of Faculty of Safety Engineering (2002-20012), now deputy of head of Department of Safety Management. Great experience in risk analysis of industrial accidents, author of publications in the area of major-accident prevention.

\section{KEY WORDS}

Risk management, SME, Emerging risk.

\section{ABSTRACT}

The risk management requires, apart from the acceptance of generally valid statutory requirements, the observance of basic principles related to this process. Those are, above all, the principles characteristic for different types of organization/system, the sphere of its influence, number of employees, and/or the knowledge advancement related to the company objectives. At present time, the standard ISO 31000 forms the basic platform but this standard underlines only the primary (compulsory) requirements and does not concentrate on specific procedures that are necessary to be observed in cases of new or emerging risks at certain premises with smaller number of SME employees. To simplify the implementation of health and safety legislation, as well as the process of integrated risk assessment with regard to new and emerging 
risks, the SMEs should create certain general rules and a succession of steps.

This contribution presents the proposal of methodology based on the ISO 31000 principles; however, it provides more complex view on the risk assessment in selected small and medium enterprises. To verify its efficiency, several industrial premises were selected, in which the verification has been performed, and subsequently the remedies and precautions were suggested for its successful implementation into practice.

\section{Introduction}

Integrated risk management requires the acceptation of legal requirements and the understanding of risk management basic principles, now described by the Standard ISO 31000. How to build integrated model which integrated emerging and existing risk for SME was one of the partial goal of 7RP project called: INtegRisk (duration of the project is from 2008-2013), which covers 69 partners from more than 24 countries. Authors of article are members of task which lead this issue (T3.1.07).

The category (Figure 1) of micro, small, and medium enterprises consists of companies employing less than 250 employees and whose annual turnover does not exceed EUR 50 million and/or balance sheet amount does not exceed EUR 43 million [1, 2].

Inside the SME category, a small enterprise is de- fined as a company employing less than 50 employees and whose annual turnover and/or balance sheet amount does not exceed EUR 10 million. Micro enterprise employs less than 10 persons and its annual turnover and/or balance sheet amount does not exceed EUR 2 million.

Information from Labor inspectorates suggested that consulting and education should be directed at small and medium enterprises more markedly. Most cases of not-observing the regulations can be found at small and medium enterprises.

The Council conclusion dated July 20th, 2007 on Community new strategy for health and safety at work invites Member States to rapidly implement the recently adopted Community Strategy 2007-2012 on health and safety at work, which will strengthen the overall approach to well-being at work and prelaunch prevention policies and improvements for workers in order to decrease the number of job-related injuries and occupational diseases, especially in sectors with their higher occurrence. The quality and degree of employees' working life and health protection represent employers' and state's cultural, social, and economic consciousness. Improvements can be achieved especially by employers' precautions and concrete programs aimed at the improvement of working and at the elimination of risks and factors conditioning job-related injuries, occupational diseases, and other injuries to health [3].

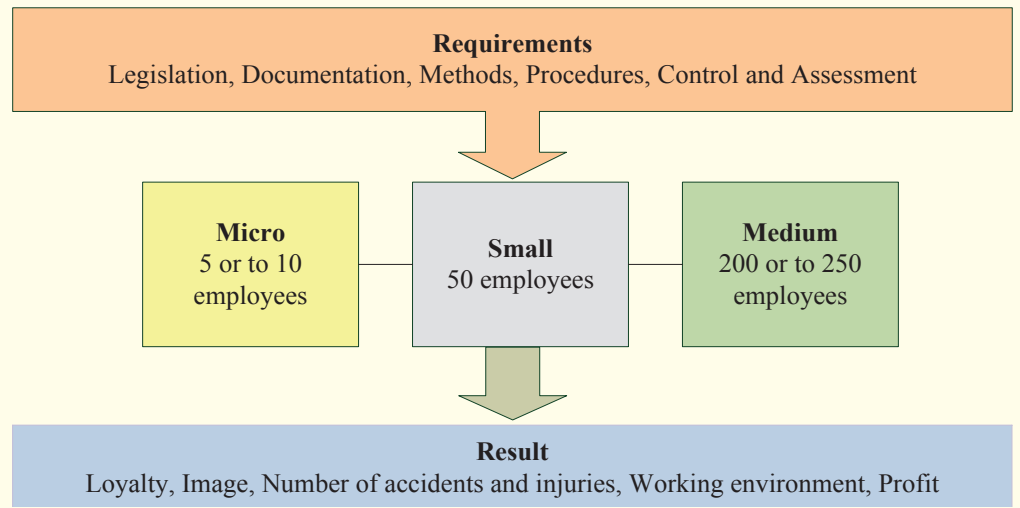

Fig. 1: Categorization of micro, small and medium enterprises [2]

\footnotetext{
The causes of problems in SMEs can be defined following:

- Unawareness of and indifference to valid legislation,

- Lack of health and safety experts,

-Deliberate non-abiding by the rules,
}

- Lack of funds,

- Investments to safety considered "burden",

- Poor awareness and knowledge of the solution of concrete problems,

- Lack of knowledge of risk assessment methods and tools. 
Observing the valid legal requirements is one of the key aspects of health and safety management, as well as that of emerging risk. Creating an effective tool for integrated risk management in SMEs is a demanding task. The position of SMEs in competitive environment can be unambiguously improved by enhancing the legal awareness of company management, by deepening the knowledge of the mutual connection between health, productivity of labor, and working environment, and by the provision of knowledge of tools and methods improving health and safety at work.

\section{Risk Management Principles}

Risk management according to ISO 31000 [5] means coordinated activities to direct and control an organization with regard to risk.

Similarly, risk management policy is defined as a statement of the overall intentions and direction of an organization related to risk management. Risk is defined as an effect of uncertainty on objectives.

The process of integration of management systems to achieve set goals is now understood as the integration of components/subsystems based on their common characteristics. In terms of efficient management, important role is played by their integration based not only on common characteristics but also on the relations between them, which form these characteristics.

It follows from these definitions, that for effective risk control it is important to specify the company objectives on strategic level and their tactical management on company's lower levels (process, workstation).

Emerging risk by the EU-OSHA describes any occupational risk that is "new" or "increasing".

By "new" is meant that:

a) the risk did not previously exist - New Internal (NI) and caused by:

- new processes $\left(\mathrm{PN}_{\mathrm{N}}\right)$,

new technologies $\left(T_{\mathrm{N}}\right)$,

new types of workplace $\left(W_{N}\right)$,

- social or organizational change $\left(\mathrm{S}_{\mathrm{N}} / \mathrm{ON}_{\mathrm{N}}\right.$ ),

b) a long-standing issue is newly considered a risk emerging due to changes in social or public perception (SNE) - (New External - NE),

c) new scientific knowledge allows a long-standing issue to be identified as a risk ( $\left.K_{N}\right)$.

The risk is "increasing" - (I): a) number of hazards leading to the risk is growing $\left(\mathrm{RH} \mathrm{H}_{1}\right.$,

b) likelihood of exposure to the hazard leading to the risk is increasing (exposure level and/or the number of people exposed), (RHPI),

c) effect of hazard on workers' health is getting worse (seriousness of health effects and/or the number of people affected), $\left(R H_{(1)}\right.$.

In general, the principle of risk control comprises respecting the following fundamental steps:

\section{Risk analysis and Risk assessment}

- Determination of the object boundaries.

- ndentification of threats and hazards, determination of likelihood and consequences.

- Risk estimation as a combination of Probability

(P) and Consequences (C).

- Risk evaluation.

- Risk assessment (acceptability, tolerability).

\section{Risk control}

Establishment of measures, i.e. determination of barriers according to legislative requirements and internal regulations (ALARP system $=$ As Low As Reasonably Practicable).

The selection of suitable methodology for risk assessment and control is based on:

- Effectiveness and simplicity of algorithm.

- Extent covering the scope and required functions of assessed system/operations.

- Comprehensibility.

- Transparent accessibility of conclusions.

- Feedback possibility.

Especially the matrix notation (the simplest is the $3 \times 3$ form for probability $P$ and consequences $C$ ) is commonly used for quantitative, semi-quantitative, and quantitative risk analysis is used in practice, for the purpose of transparency and adherence to basic algorithm steps.

For the purpose of health and safety at work management, the equation stating the risk as a combination of two parameters $\mathrm{P}$ (Probability) and $C$ (Consequences) is used. Sometimes additional parameter can be added (so called extended risk definition) The third parameter can be Frequency, Exposition or possibility of Averting. Nowadays, the implementation of requirements to assess the probability of human error (i.e. not only the failure of assessed system functionality) arising from BS OHSAS 18001 standard.

According to the manual IRM (A Structured Approach to Enterprise Management), the Risk man- 
agement process is presented as a list of coordinated activities, represented by 7Rs and 4Ts [WwW. theirm.org]:

- Recognition or identification of risks

- Ranking or evaluation of risks

- Responding to significant risks

Tolerabe (To)

Treat

Transfer

Terminate

- Resourcing control

- Reaction planning

- Reporting and monitoring risk performance

- Reviewing the risk management framework.

\section{SME Integrated Risk Management Methodology}

Proposed methodology is based on the intersection of two areas that can be sources of existing and emerging risks, following from the layout of assessed system and its activities (holistic approach). It is based on the Risk Radar philosophy (T-technological, E-environmental, S-Socio-Political, Ef-Economic/Financial, R- Regulatory/Legal), and on the method applied to Emergent risk by Bryan Richardson and Peter Gerzon (IRM - Institute of Risk Management) $[6,7]$.

In order to make the methodology of integrated risk assessment more effective and to adhere to the legal requirements for SMEs, the methodology for the step of threat identification was divided into two groups:

Table 1: Hazards divided into seven specified areas

\begin{tabular}{|c|c|c|}
\hline n. & Hazards/topics & Description \\
\hline I. & \multicolumn{2}{|l|}{ Socio-Political } \\
\hline I.1 & Political & $\begin{array}{l}\text { Related to changes in political } \\
\text { systems (change of gover- } \\
\text { nment) or the activities of } \\
\text { political representatives. }\end{array}$ \\
\hline 1.2 & $\begin{array}{l}\text { Direct Public } \\
\text { Pressure }\end{array}$ & $\begin{array}{l}\text { Public activities, e.g. protests } \\
\text { boycotts that may affect } \\
\text { political and legal decisions } \\
\text { and processes. }\end{array}$ \\
\hline II. & \multicolumn{2}{|c|}{ Regulatory-Legal } \\
\hline II.1 & Legal & $\begin{array}{l}\text { Related to various ways of } \\
\text { penalizations in cases of } \\
\text { exceeding certain limits in } \\
\text { given areas. }\end{array}$ \\
\hline
\end{tabular}

\begin{tabular}{|c|c|c|}
\hline 11.2 & Regulatory & $\begin{array}{l}\text { Changes and requirements } \\
\text { given by government decre- } \\
\text { es, legal statutes, agreements } \\
\text { and their influence on com- } \\
\text { pany activities or objectives. }\end{array}$ \\
\hline III. & \multicolumn{2}{|c|}{ Illegal activity - security } \\
\hline III.1 & Security & $\begin{array}{l}\text { Means to protect life and pro- } \\
\text { perty in short- and long-term } \\
\text { prospect, terrorism. }\end{array}$ \\
\hline III.2 & $\begin{array}{l}\text { Criminal } \\
\text { Activity }\end{array}$ & $\begin{array}{l}\text { Various forms of criminal acti- } \\
\text { vities, thefts, deceptions. }\end{array}$ \\
\hline IV. & \multicolumn{2}{|c|}{ Design, Operation, Maintenance } \\
\hline IV.I & Technology & $\begin{array}{l}\text { New technologies and mate- } \\
\text { rials, availability of information } \\
\text { and scientific studies. }\end{array}$ \\
\hline IV.2 & Engineering & $\begin{array}{l}\text { Application of means to } \\
\text { prevent failure states and } \\
\text { securing of functional requi- } \\
\text { rements during the life cycle } \\
\text { of object (service/project) }\end{array}$ \\
\hline IV.3 & Requirements & $\begin{array}{l}\text { Communication and specifi- } \\
\text { cation of requirements, e.g. in } \\
\text { the design stage during the } \\
\text { life cycle of object (service/ } \\
\text { project). }\end{array}$ \\
\hline V. & \multicolumn{2}{|l|}{ Environmental } \\
\hline V.I & Environment & $\begin{array}{l}\text { Influences of environment, } \\
\text { climatic changes, changes of } \\
\text { environment due to human } \\
\text { activities influence. }\end{array}$ \\
\hline VI. & \multicolumn{2}{|c|}{ Economical/Financial } \\
\hline VI.1 & $\begin{array}{l}\text { Financial and } \\
\text { Economic }\end{array}$ & $\begin{array}{l}\text { National and international } \\
\text { financial changes (e.g. ex- } \\
\text { change rate variation, prices } \\
\text { of products and services). }\end{array}$ \\
\hline VII. & \multicolumn{2}{|l|}{ Human Factors } \\
\hline VII.1 & Culture & $\begin{array}{l}\text { Level of organization culture, } \\
\text { ways of management, moti- } \\
\text { vations. }\end{array}$ \\
\hline VII.2 & $\begin{array}{l}\text { Human } \\
\text { Factors }\end{array}$ & $\begin{array}{l}\text { Human errors occurrence, } \\
\text { possible occurrence of delibe- } \\
\text { rate and unintentional errors. }\end{array}$ \\
\hline VII.3 & Knowledge & $\begin{array}{l}\text { Level of education, training, } \\
\text { lack of knowledge and experi- } \\
\text { ence in given field/activity. }\end{array}$ \\
\hline
\end{tabular}

1. Micro and Small enterprises (MaS - Micro and Small) with the number of employees up to 20 - Table 2.

2. Small and Medium enterprises (SaM - Small and Medium) with the number of employees over 20 - Table 3. 
Of course, the choice of tools depends on the extent of activities and graveness of danger (e.g. storage of larger amount of dangerous substances).

For MaS, the criteria for the identification of emerging risks were simplified (see emerging risk by EU-OSHA) as follows:

a) new hazards without sufficient knowledge and experience and the support of valid legislation ( $\mathrm{N}$ - new), b) likelihood of exposure to the hazard leading to the risk is increasing (exposure level and/or the number of people exposed), partial and/or no legislation or knowledge (RHpl),

c) effect of hazard on workers' health, environment, property is getting worse (seriousness of health effects and/or the number of people affected), partial and/or no legislation or knowledge ( $\mathrm{RHCl}$.

Criteria for the management of existing risks are sectioned as follows:

a) existing full legislation support, availability of standards and instructions, case studies (LaS - Legislation and Standards),

b) defined by legislation but unavailable manuals or methodic instructions how to manage it, implemented working instructions (LaW - Legislation and Workorders),

c) existing but not fully implemented legislation requirements, unavailable manuals or methodic instructions how to manage it, unimplemented internal instructions (L - legislation).

Table 2: Classification of hazards according to the type and identification of emerging risk for Micro and Small enterprises MaS

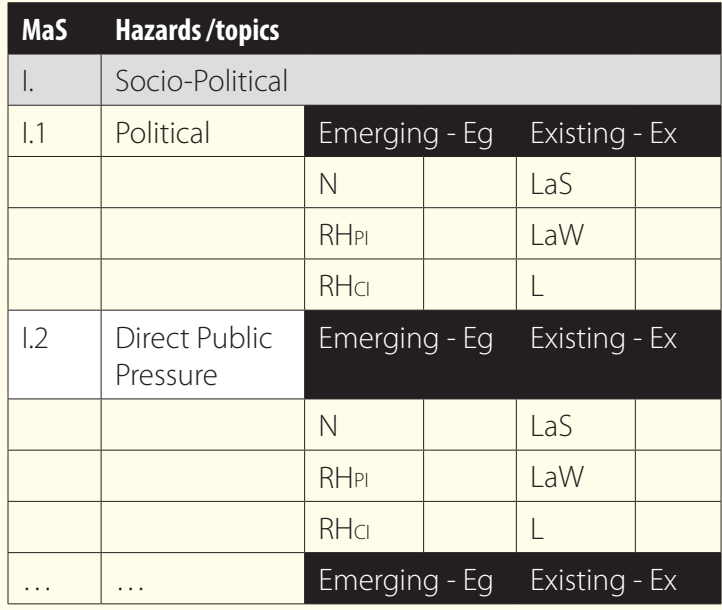

The definitions of criteria for the determination of probability or exposition were based on the fol- lowing assumptions:

\section{A. Long lasting danger -3 ,}

B. Danger limited to certain time - 2,

C. Danger occurs rarely or only during irregular activities $-1$.

The following areas and weights of impact (from 1 to 3 for each) were defined for consequences (Tables 4).

Table 3: Classification of hazards according to the type and identification of emerging risk for small and medium enterprises SaM

\section{SaM Hazards/topics}

\begin{tabular}{|c|c|c|}
\hline I. & Socio-Political & \\
\hline I. 1 & $\begin{array}{lll}\text { Political ... } & \text { Emerging } \\
& -E g\end{array}$ & Existing - Ex \\
\hline
\end{tabular}

\begin{tabular}{|l|l|l|}
\hline IV. & \multicolumn{2}{|c|}{ Design, Operation, Maintenance } \\
\hline IV.I & Technology & $\begin{array}{l}\text { Emerging } \\
\text { - Eg }\end{array}$ \\
\hline
\end{tabular}

\begin{tabular}{|c|c|c|c|}
\hline & & & \\
\hline & & $P_{N}$ & Noise \\
\hline & & $T_{N}$ & Vibrations \\
\hline & & $W_{N}$ & Radiation \\
\hline & & SN/ON & Mechanical \\
\hline & & SNE & Electrical \\
\hline & & $\mathrm{K}_{\mathrm{N}}$ & Light factors \\
\hline & & \multirow{2}{*}{$\mathrm{RH}$} & $\begin{array}{l}\text { Heat and } \\
\text { cold }\end{array}$ \\
\hline & & & Slipping, fall \\
\hline & & RHPI & $\begin{array}{l}\text { Emission of } \\
\text { dangerous } \\
\text { materials } \\
\text { and substan- } \\
\text { ces }\end{array}$ \\
\hline & & \multirow{2}{*}{$\mathrm{RHCl}$} & $\begin{array}{l}\text { Fire/explo- } \\
\text { sion }\end{array}$ \\
\hline & & & Lightning \\
\hline IV.2 & $\begin{array}{l}\text { Engineering } \\
\ldots\end{array}$ & $\begin{array}{l}\text { Emer- } \\
\text { ging } \\
- \text { Eg }\end{array}$ & Existing - Ex \\
\hline
\end{tabular}

Table 4: Consequences/Impacts of risks identified in seven Areas

\begin{tabular}{|l|l|l|}
\hline A & Consequence & Description \\
\hline I. & Delay & $\begin{array}{l}\text { Danger influences the supply/deli- } \\
\text { very of service }\end{array}$ \\
\hline II. & $\begin{array}{l}\text { Refusal to } \\
\text { proceed }\end{array}$ & $\begin{array}{l}\text { Danger can cause the loss of } \\
\text { customer }\end{array}$ \\
\hline
\end{tabular}




\begin{tabular}{|l|l|l|}
\hline III. & Change Limit & $\begin{array}{l}\text { Danger can influence specified } \\
\text { limits }\end{array}$ \\
\hline IV. & Disaster & $\begin{array}{l}\text { Danger can cause major accidents } \\
\text { affecting people, environment, } \\
\text { property }\end{array}$ \\
\hline V. & $\begin{array}{l}\text { Operational } \\
\text { Failure }\end{array}$ & $\begin{array}{l}\text { Loss of function influences the } \\
\text { performance and availability of } \\
\text { plant/organization }\end{array}$ \\
\hline VI. & $\begin{array}{l}\text { Lifetime } \\
\text { Failure }\end{array}$ & $\begin{array}{l}\text { Danger affects the lifetime of ob- } \\
\text { ject as well as the stated objectives }\end{array}$ \\
\hline VII. & $\begin{array}{l}\text { Finance/Com- } \\
\text { mercial }\end{array}$ & $\begin{array}{l}\text { Danger affects the planned costs, } \\
\text { can cause unwanted losses }\end{array}$ \\
\hline
\end{tabular}

Standard type $3 \times 3$ risk matrix has been selected according to stated criteria for probability and consequences of evaluated risk - Figure 2.

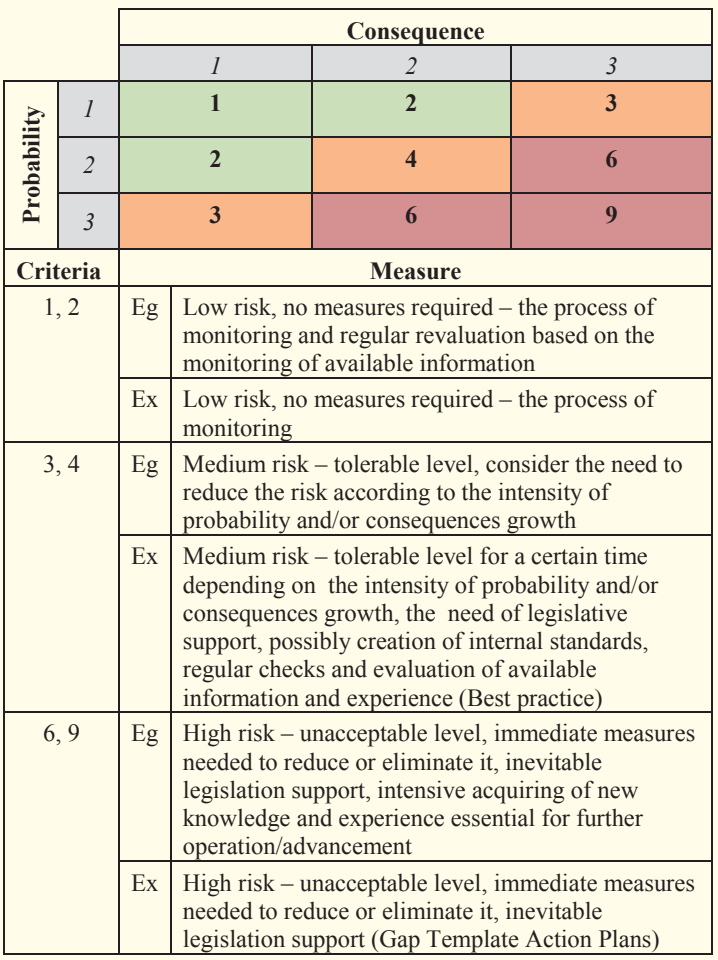

Fig. 2: Risk matrix for existing and emerging risk management

\section{Conclusion}

The application of proposed model for SMEs proved the possibility to categorize existing and emerging risks and to perform their integrated assessment. The integrated approach to its management and control, i.e. adopting measures covering the largest possible range of identified hazards, is a bigger problem. Appropriately chosen structure of KPI (Key Performance Indicators) and their specifica- tion related to stated company objectives can be of help during this decision making.

\section{Acknowledge}

The research has been supported and obtained financial fund from Seventh Frame program iNTegRisk based on Grand Agreement Nr. .CP-IP 213345-2 and along with Slovak Research and Development Agency based on Agreement Nr. DO7RP-0019-08.

\section{Conflict of Interest}

"The authors declare no conflict of interest".

\section{References}

[1] Pačaiová, H., Sinay, J., Glatz, J. Bezpečnost’ a riziká technických systémov [Safety and risks of technical systems]. 1. ed. Košice :TU, SjF, 2009. 246 pp. ISBN 978-80-553-0180-8.

[2] Nová definícia malých a stredných podnikov [New definition of small and medium enterprises] (MSP): [cit 2013-0110]. Available at: <apvv.sk/doc/statna.../nova_definicia_ malych_a_strednych_podnikov.rtf>.

[3] Koncepcia bezpečnosti a ochrany zdravia pri práci v Slovenskej republike na roky 2008 až 2012 [Concept of health and safety at work in the Slovak Republic for years 2008 - 2012]: [cit 2013-01-10]. Available at: <www.employment.gov.sk/ index.php?id=12980>

[4] Bernatík, A., Pešák, M. Risk Assessment in Small and Medium-sized Enterprises, 11TH INTERNATIONAL SYMPOSIUM LOSS PREVENTION AND SAFETY PROMOTION; PRAHA 1.-3.6. 2004, ISBN 80-02-01574-6, PP.1144-1152.

[5] ISO 31000:2009 Risk management - Principles and guidelines.

[6] Richardson, B., Gerson, P. Emerging risk. <www.theirm.org>

[7] Pačaiová, H., Bodisová, V. Prevádzka a údržba CNC stroja v spoločnosti HUTO s.r.o. [Operation and maintenance of CNC machines at HUTO Ltd.] Diploma work. 2012.

[8] Pačaiová, H., Nagyová, A., Bernatík, A. Verification of Risk Assessment methodology in SME - Case Study. In.: Integrisk 2013, Sturttgart, ISBN 978-3-943356-71-7 